\title{
Application of Blended Teaching Mode in Comprehensive English Course
}

\author{
Weilian Ma, Jianhui Zhang \\ College of Foreign Language Education and International Business, Baoding University, Baoding, China \\ Email: linda0180@126.com
}

How to cite this paper: Ma, W. L., \& Zhang, J. H. (2021). Application of Blended Teaching Mode in Comprehensive English Course. Creative Education, 12, 647-652. https://doi.org/10.4236/ce.2021.123044

Received: January 18, 2020

Accepted: March 22, 2021

Published: March 25, 2021

Copyright (c) 2021 by author(s) and Scientific Research Publishing Inc. This work is licensed under the Creative Commons Attribution International License (CC BY 4.0).

http://creativecommons.org/licenses/by/4.0/

\begin{abstract}
Comprehensive English is one of the fundamental courses for English majors and it aims at cultivating students' basic English skills, and laying solid foundation for higher grades. However, the current teaching mode cannot fulfill the needs of the information era any longer due to its old teaching materials and traditional teaching methods. This paper tries to explore the blended teaching mode from three stages-pre-class, in-class and post-class based on the Internet+ background to stimulate students' autonomous learning ability, improve their language competence and comprehensive attainment.
\end{abstract}

\section{Keywords}

Blended Teaching Mode, Comprehensive English Course, Internet+, Network Teaching Platform

\section{Introduction}

With the development of English education and the progress of modern educational technology in China, it is the current trend to explore a blended teaching mode based on network and classroom teaching. Comprehensive English course plays quite an important role for English majors and the current teaching situation of the course is not quite desirable. Traditionally, teachers are the center of teaching activities and the imparter of knowledge and students are the passive receivers of information. Classroom is the main environment of teaching and provides the stage for teachers to perform. As a cognitive subject, students are always in a passive position in the whole teaching process and their learning initiative is ignored, which is inconsistent with the requirements of modern society on talent cultivation ( $\mathrm{Lu}, 2019)$. Therefore, it is imperative to change the traditional teaching mode. 
The last two decades have witnessed the rapid development of information technology which has greatly changed people's life. College students are skilled users of mobile technology, which has also shaped their learning habits and preference. Teachers are supposed to find more positive and active ways to take advantage of mobile devices. It seems that to integrate mobile technology into in-class teaching and online learning is a good choice. Blend-teaching mode is a combination of traditional classroom teaching methods and online teaching forms under the guidance of various theories. The blend-teaching mode uses a variety of media, teaching materials and technical forms to cover the content, environment and teaching methods involved in teaching activities. Systematic design, media, evaluation feedback, etc., in order to achieve a comprehensive teaching form that focuses on individual cognitive, skill improvement and emotional training, is a new teaching method to improve students' learning effect. (Power, 2008). The blended teaching mode combines the advantages of traditional teaching methods with the advantages of network characteristics, which not only gives full play to the leading role of teachers in guiding, inspiring and monitoring the teaching process, but also fully embodies the initiative, enthusiasm and creativity of students as the main body of the learning process (Lin, 2017). According to Bruner's educational theory, students are active receivers of knowledge and processors of information. Constructivist learning theory advocates that learners should be motivated to study independently, and learners should actively explore and discover the knowledge they have learned. The blended teaching can teach students in accordance with their aptitude to the greatest extent.

At present, there are many scholars studying this issue abroad, they believed that blended learning is the combination of two learning environments and they advocated the combination of various network technologies, various teaching methods and techniques, and teaching techniques and specific tasks. In December 2003, professor He kekang officially advocated "blended learning" in China for the first time at the 7th Global Chinese Computer Education Application Conference, which kicked off the domestic research on "blended learning". Research on blended learning in China has also yielded fruitful results.

\section{Blended Teaching Mode Applied in Pre-Class Preparation}

In the pre-class preparatory process, teachers are supposed to collect, organize, and produce network resources, and make task lists to upload to the network learning platform. In the real teaching practice, the teacher should measure and analyze the learning situation of each student and make decision. Let's take one teaching class as an example to illustrate the teaching practice. There are $30 \mathrm{stu}-$ dents in the class, and in order to facilitate teaching management and students' interaction, the teacher divides the whole class into six different study groups. Each study group has five members, and each has different tasks to fulfill according to the topic they deal with. We may take unit 2 How Reading Changed My Life from Contemporary College English book 3 as an example. In this essay, 
Anna Quindlen tells readers with her own experience how reading can change one's life. She mentions many world-famous masterpieces, which are quite worth reading for English majors. The teacher chooses six masterpieces Gone with the Wind, Jane Eyre, A Tale of Two Cities, Pride and Prejudice, Moby-Dick, A Little Prince for the students to explore and analyze. Each study group is in charge of one book. Students are supposed to search, read, analyze, and sort out the information they collect from the Internet. Finally they can organize and summarize their materials and present their results to the rest of the students in the form of ppt. After the class, each group will upload their final results to the teaching platform Chaoxing Xuexi Tong to share their achievements with all the classmates. During the process of fulfilling the tasks, students have more chances to read, think and reflect on the materials, which can also develop their critical thinking ability. At the same time students can enjoy the beauty of the authentic English like "It was the best of times, it was the worst of times, it was the age of wisdom, it was the age of foolishness..." in A Tale of Two Cities.

\section{Blended Teaching Mode Applied in In-Class Activities}

Communicative Language Teaching is the most suitable for the face-to-face teaching in class. It is an approach to language teaching that emphasizes interaction as both the means and the ultimate goal of study (Lin et al., 2018). Language learners learn and practice the target language through the interaction with one another and the instructor by using authentic texts. The aim of this study was to develop a deep understanding of authentic interaction in English as a foreign language classroom so as to improve communicative language teaching approach. It emphasizes the interaction between teachers and students, students and students. It also advocates a student-centered classroom and underlines the importance of autonomous learning and collaborative learning.

In face-to-face teaching, teachers and students will participate in the interaction, transmission and feedback of information, reflecting the student-centered education concept. Each teaching link organizes the teaching content according to the students' cognitive development level and learning feedback information. Because students have a preliminary understanding of the basic knowledge in the pre-class preparation process and feedback the problems encountered in learning to teachers through the network learning platform, teachers will focus on solving the difficult problems of students' feedback in the classroom and explain them according to the actual situation of students' mastery of knowledge, so the teaching process is more targeted, reflecting the teaching thoughts of individualized quality education.

For example, in face-to-face teaching of How Reading Changed My Life, the teacher organizes a group debate in class. There are six groups, and each group chooses one topic. The debating topics are: 1) "It is a serious problem that people don't read" vs. "It is not a serious problem that people don't read"; 2) "Reading itself is a sure guarantee to make us wise and fine human beings" vs. "Reading itself is not a sure guarantee to make us wise and fine human beings"; 
3) "E-books reading will replace physical books reading" vs. "E-books reading will not replace physical books reading". The topics are closely related to the essay and can stimulate students' interest to think, discuss, and share their ideas and reflection.

Through mutual assistance, collaboration and sharing, the members of the group jointly completed the task. Teachers organize the presentation and sharing the results of group discussions in class. Through mutual discussion and exchange, teachers help students clearly demonstrate the advantages and disadvantages of the project, and realize the expansion and deepening of knowledge in the process of exchange and sharing. Student group discussion link cannot only exercise students' research and exploration ability, but also improve the ability of cooperation and interaction. In the process of classroom teaching and using the network teaching platform to carry out teaching, teachers and students should make a periodic summary and reflection. By reviewing and summarizing the main points of learning, the internal relationship between knowledge is explored in depth, and then the regularity of knowledge is found, so as to achieve the goal of improving the quality and effect of learning. When it comes to the essay of unit 1 Your College Years from book 3, all the students are required to make a public speech about "In what ways do you think college is a time of personal growth and expansion?" Students may combine what they have gained in the essay with their personal experience to prepare for the public speech. It is also a summary to the text and a reflection on themselves. At the same time, public speech is a perfect practice for English majors. After the class, students will also submit their speeches to the network teaching platform.

\section{Blended Teaching Mode Applied in Post-Class Assignment}

Teaching time is limited, but reflection to questions is limitless. Under the era of Internet+, students have more access to vast, authentic, rich and colorful resources (Wang et al., 2018). College students are fast learners to the mobile network technology, and educators also have to study the characteristics of Internet+ to meet the new challenge. Post-class assignments aim at knowledge expansion. The teacher will provide personalized guidance and assignment to students based on their pre-class and in-class learning situation. Students have to finish their assignments and share their works with fellow classmates. They also make comment on others' works. The teacher will give the feedback to students. Based on the assessment from the teacher and classmates, students can make reflection on themselves so as to consolidate the acquired knowledge.

We may take unit 3 Groundless Beliefs from book 4 as an example. This essay classifies the propositions according to their grounds, probably people may be astonished at the number of propositions which are groundless in our daily life. When the epidemic of Covid-19 first broke out, a wave of hate crimes against Asians has cascaded throughout Western countries. Some malicious people even called it "Wuhan virus" or "China virus". A Fox News host even demanded China officially apologize to the world for causing the epidemic. In response to this is- 
sue, the teacher assigns a task to the students, requiring them to write their thinking about the groundless accusations against China on the network teaching platform Chaoxing Xuexi Tong. After the students submit their assignments to the platform, the teacher reviews the assignments, checks the message information of the discussion board, finds out the typical problems in the students' study in time, answers the students' questions, and gives guidance to the group discussion activities in time. The students can use the interactive function of the platform to evaluate others' homework. They can put forward their own opinions and suggestions and find their own shortcomings. It is a good way to attain the knowledge and skill objectives for students. The teacher is delighted to see that most students could think about the issue from a critical, rational and reasonable perspective. In the end, the teacher uploads a video made by the hostess LiuXin from GGTN and highlights her comments on this issue: "A disease can break out in any part of the world because of all kinds of reasons. Does the world ask these cities, villages, or countries to apologize? No, because viruses don't care about borders. No, because it's counterproductive". When the students learn to treat various opinions appropriately they can make sound judgment independently. In this process, they set up correct mainstream values, cultivate a global vision, and develop a sense of citizenship.

\section{Conclusion}

This paper carries out the teaching practice of integrating Comprehensive English Course with the blended teaching mode through effective teaching design. It indicates that construction of this teaching mode can be done through three stages of pre-class preparation, in-class activities, and post-class assignment. The combination of in-class teaching with the off-class activities based on the Internet+ background provides the students with an autonomous and personalized learning system.

The blended teaching mode under the background of "Internet+" aims at applying the open characteristics of Internet information technology to enable Internet technology to truly integrate into the teaching process of teachers, and to diversify teachers' teaching methods on the basis of opening and sharing teaching resources, so as to achieve comprehensive learning ability under the effective guidance of teachers, enhance and improve students' interest and autonomy in learning, better realize the absorption and transformation of knowledge, and improve the teaching effect from multiple perspectives.

The blended teaching mode expands and enriches the content of college English teaching, makes English teaching colorful, and improves students' motivation and initiative. It eliminates time and space restrictions, broaden the scope of education. Students are no longer confined to a fixed time and place to learn English in class. They can use electronic devices such as computers and mobile phones to learn English in their homes, dormitories, libraries and public places (Wang \& Liu, 2015). They can also receive lectures from other teachers in any place to expand the teaching space. Students can learn independently through 
courses stored in the cloud to optimize their personal time allocation. Besides, the blended teaching mode could strengthen the depth of education and improve the quality of teaching. It is not only the use of online platform, nor the simple construction of digital teaching resources, but to enhance the depth of learning, and enrich the teaching content. Students carry out English learning in a variety of ways, and use the Internet and other platforms for English communication, listening, speaking and writing. At the same time, teachers can evaluate students' interests and characteristics according to their learning records on the Internet, adjust teaching plans and methods, and improve learning efficiency. Applying the blended teaching mode to Comprehensive English Course has a positive effect on the reform and progress of college English teaching.

\section{Conflicts of Interest}

The author declares no conflicts of interest regarding the publication of this paper.

\section{References}

Lin, F. (2017). Research on a New Mixed Teaching Model for Computer Major Courses Based on Flip Classroom. Guangxi Education, No. 15, 90-91.

Lin, L, Mao, X. Y., \& Zhang J. B. (2018). Research on Mixed Teaching Mode of Information Security Architecture Course Supported by Massive Open Online Course. Higher Education Forum, No. 3, 28-31.

Lu, C. (2019). Research on the Mixed Teaching Model of Probability Theory and Mathematical Statistics Based on SPOC. Teachers, No. 8, 30-31.

Power, M. (2008) The Emergence of a Blended Online Learning Environment. MERLOT Journal of Online Learning and Teaching, 4, 37-39.

Wang, C., \& Liu, N. (2015). Internet+ Education: Education Revolution in the Mobile Internet Era. Beijing: China Economic Publishing House, 7, 147-149.

Wang, Y., Han, X., \& Yang, J. (2018). Revisiting the Blended Learning Literature: Using a Complex Adaptive Systems Framework. Educational Technology \& Society, 3, 25-28. 